\title{
Evaluation of Treatment Volume Determination for Irradiation of chordoma: an Original Article
}

\author{
Omer Sager $^{1}$, FerratDincoglan ${ }^{1}$, Selcuk Demiral ${ }^{1}$, Murat Beyzadeoglu ${ }^{1}$ \\ ${ }^{1}$ Department of Radiation Oncology; University of Health Sciences, Gulhane Medical Faculty, \\ Ankara, Turkey. \\ *Corresponding Author: Omer Sager, University of Health Sciences, Gulhane Medical Faculty, \\ Department of Radiation Oncology, Gn.TevfikSaglam Cad. 06018, Etlik, Kecioren, Ankara /TURKEY
}

\begin{abstract}
Objective: Chordomas are relatively rare tumors arising from the remnants of the notochord. These locally aggressive tumors may cause destruction of bone and extension into adjacent soft issues. Radiation therapy (RT) may be used as a treatment modality for management of chordomas. Chordomas are considered as radio resistant tumors, and high doses may be required to achieve durable local control rates with irradiation. In this context, treatment volume definition is a critical component of safe and effective radio therapeutic management.
\end{abstract}

Materials and Methods: Meticulous assessment has been performed on an individual basis for consideration of lesion size, location, symptomatology, patient preferences, and predicted outcomes of management. Treatment volume determination by use of multimodality imaging within corporation of MRI or by computed tomography (CT)-simulation images only was comparatively assessed for patients irradiated for chordoma in our study.

Results: Optimal target coverage and sparing of normal tissues was prioritized in radiation treatment planning. In our study, ground truth target volume has been found to be identical with treatment volume determination based on CT-MR fusion based imaging.

Conclusion: Toxicity profile of radiation delivery is an important aspect of radio therapeutic management given the typically critical location of chordomas in intricate association with vital neurovascular structures. Precision and accuracy in treatment volume definition is a critical component of irradiation for chordoma. Incorporation of MRI in treatment volume determination procedure can be considered for improving the optimization of target volume definition for precise radiation delivery despite the need for further supporting evidence.

Keywords: chordoma, radiation therapy $(R T)$, magnetic resonance imaging (MRI), irradiation

\section{INTRODUCTION}

Chordomas are relatively rare tumors arising from the remnants of primitive embryonal cells also referred to as the notochord [1-3]. Most frequent locations for chordoma include the skull base and sacrum. A slow growth pattern with an indolent disease course is common, however, these locally aggressive tumors may cause destruction of bone and extension into adjacent soft tissues [4,5]. Affected patients may suffer from several symptoms depending on lesion location. Surgery is a main therapeutic modality for management of chordomas, however, complete surgical resection may not be feasible for tumors in the vicinity of critical neurovascular structures, and local recurrences may represent a considerable concern [5-7]. In this context, radiation therapy (RT) may be used as a treatment modality to address residual disease or recurrences, and also as the primary mode of management in selected patients [7-10]. Irradiation by use of conventionally fractionated RT (CFRT) or radio surgery as Stereotactic Radio surgery (SRS), Fractionated Stereotactic Radiation Therapy (FSRT), and Stereotactic Body Radiation Therapy (SBRT) or Stereotactic Ablative Body Radiotherapy (SABR) may serve as a viable therapeutic option with promising results for management of various central nervous system (CNS) disorders and for many other benign and malignant tumors throughout the human body [11-32].As for chordomas, the role of irradiation has been addressed in several studies [7-10]. Chordomas are considered as radio resistant tumors, and high doses may be 
required to achieve durable local control rates with irradiation [33].Toxicity profile of radiation delivery is an important aspect of radio therapeutic management given the typically critical location of chordomas in intricate association with vital neurovascular structures. In this context, treatment volume definition is a critical component of safe and effective radio therapeutic management. In this study, we evaluated incorporation of multimodality imaging for treatment volume determination for irradiation of chordomas.

\section{Materials ANd MethodS}

Treatment volume determination by use of multimodality imaging with incorporation of MRI or by computed tomography (CT)simulation images only was comparatively assessed for patients irradiated for chordoma in our study. Ground truth target volume used as reference for actual treatment and comparison purposes has been determined by board-certified radiation oncologists after thorough evaluation, colleague peer review, collaboration, and ultimate consensus. Meticulous assessment has been performed on an individual basis for consideration of lesion size, location, symptomatology, patient preferences, and predicted outcomes of management. CTsimulator (GE Lights peed RT, GE Healthcare, Chalfont St. Giles, UK) has been utilized for radiation treatment simulation for RT planning at our department. Planning CT images have been acquired and then transferred to the contouring workstation (Sim MD, GE, UK) for delineation of treatment volumes and surrounding critical organs. Either CTsimulation images only or fused CT and MR images have been used for treatment volume determination for irradiation. Treatment volume definition with CT only and by incorporation of CT-MR fusion has been assessed comparatively. Definition of the ground truth target volume has been performed by board-certified radiation oncologists after thorough evaluation, collaboration, colleague peer review and ultimate consensus to be utilized for actual treatment as well as for comparative analysis. Synergy (Elekta, UK) linear accelerator (LINAC) has been used for treatment delivery with routine utilization of Image Guided Radiation Therapy (IGRT) techniques.

\section{RESULTS}

Radiation treatment planning has been performed by use of the available treatment planning systems at our tertiary cancer center.
Optimal target coverage and sparing of normal tissues was prioritized in radiation treatment planning. Synergy (Elekta, UK) LINAC has been utilized for RT administration. Irradiation treatment volume definition by CT-only imaging and by CT-MR fusion based imaging has been comparatively evaluated. In our study, ground truth target volume defined by boardcertified radiation oncologists after thorough assessment, collaboration, colleague peer review, and ultimate consensus has been found to be identical with treatment volume determination based on CT-MR fusion based imaging.

\section{DISCUSSION}

Chordomas are relatively rare but locally aggressive tumors with predilection for local recurrence. RT with conventional fractionation or radio surgery has been utilized for improving local control rates and for definitive management in selected cases. Recent years have witnessed considerable achievements in the discipline of radiation oncology with introduction of adaptive RT approaches and state of the art treatment delivery techniques including incorporation of automatic segmentation techniques, molecular imaging methods, Adaptive Radiation Therapy (ART), Image Guided Radiation Therapy (IGRT), Intensity Modulated Radiation Therapy (IMRT), Breathing Adapted Radiation Therapy (BART), and stereotactic irradiation with SRS, FSRT, and SABR [34-44]. Sophisticated technologies including radio surgery may facilitate focused irradiation with robust immobilization and offer improvements in precision and accuracy of radiation treatments, nevertheless, treatment volume determination becomes more important given the high doses of radiation in a single or a few fractions. Accuracy in treatment volume determination is an integral part of successful chordoma irradiation. Defining larger than actual treatment volumes may significantly increase exposure of adjacent normal tissues which may result in excessive radiation induced toxicity. On the other hand, inadequate encompassing of the target volume may lead to treatment failure. At this point, there is an obvious need for improved target volume determination and localizaton. IGRT techniques may offer improved target localization, and combined use of registered CT and MR images may assist in optimization of treatment volume definition for precise RT delivery. Multimodality imaging for irradiation treatment volume determination has been assessed in 
several studies [45-63]. Our study may add to the literature with regard to addressing of multimodality imaging for treatment volume determination for chordoma irradiation.

In conclusion, precision and accuracy in treatment volume definition is a critical component of irradiation for chordoma. Incorporation of MRI in treatment volume determination procedure can be considered for improving the optimization of target volume definition for precise radiation delivery despite the need for further supporting evidence.

\section{REFERENCES}

[1] Sun X, Hornicek F, Schwab JH (2015) Chordoma: an update on the pathophysiology and molecular mechanisms. Curr Rev Musculoskelet Med 2015 8(4):344-352.

[2] Chauvel A, Taillat F, Gille O, Rivel J, Vital JM, et al. (2005) Giant vertebral notochordal rest: a new entity distinct from chordoma. Histopathology 47(6): 646-649.

[3] McMaster ML, Goldstein AM, Bromley CM (2001) Chordoma: incidence and survival patterns in the United States. Cancer Causes Control 12: 1-11.

[4] Chugh R, Tawbi H, Lucas DR, Biermann JS, Schuetze SM, et al. (2007)Chordoma: the nonsarcoma primary bone tumor. Oncologist 12(11):1344-1350.

[5] Samii A, Gerganov VM, Herold C, Hayashi N, Naka T, et al. (2007) Chordomas of the skullbase: surgical management and outcome. J Neurosurg 107:319-324.

[6] Lanzino G, Dumont AS, Lopes MB, Laws ER (2001) Skull base chordomas: overview of disease, management options, and outcome. NeurosurgFocus 10:E12.

[7] Walcott BP, Nahed BV, Mohyeldin A, Coumans JV, Kahle KT, et al. (2012) Chordoma: current concepts, management, and future directions. LancetOncol 13: 69-76.

[8] Pennicooke B, Laufer I, Sahgal A, Varga PP, Gokaslan ZL, et al. (2016) Safety and Local Control of Radiation Therapy for Chordoma of the Spine and Sacrum: A Systematic Review. Spine (PhilaPa 1976)41 Suppl 20(Suppl 20):S186-S192.

[9] Casali PG, Stacchiotti S, Sangalli C, Olmi P, Gronchi A (2007) Chordoma. Curr Opin Onco 119:367-370.

[10] Catton C, O'Sullivan B, Bell R, Laperriere N, Cummings B, et al. (1996) Chordoma: longterm follow-up after radical photon irra diation. RadiotherOncol41:67-72.

[11] Sager O, Beyzadeoglu M, Dincoglan F, Demiral S, Gamsiz H, et al. (2020) Multimodality management of cavernous sinus meningiomas with less extensive surgery followed by subsequent irradiation: Implications for an improved toxicity profile. $\mathbf{J}$ Surg Surgical Res 6: 056-061.

[12] Beyzadeoglu M, Sager O, Dincoglan F, Demiral S, Uysal B, et al. (2020) Single Fraction Stereotactic Radiosurgery (SRS) versus Fractionated Stereotactic Radiotherapy (FSRT) for Vestibular Schwannoma (VS). J Surg SurgicalRes 6: 062-066.

[13] Dincoglan F, Beyzadeoglu M, Sager O, Demiral S, Uysal B, et al. (2020) A Concise Review of Irradiation for Temporal Bone Chemodectomas (TBC). Arch OtolaryngolRhinol 6: 016-020.

[14] Dincoglan F, Sager O, Uysal B, Demiral S, Gamsiz H, et al. (2019) Evaluation of hypofractionated stereotactic radiotherapy (HFSRT) to the resection cavity after surgical resection of brain metastases: A singlecent erexperience. Indian J Cancer 56: 202-206.

[15] Dincoglan F, Sager O, Demiral S, Gamsiz H, Uysal B, et al. (2019) Fractionated stereotactic radiosurgery for locally recurrent brain metastases after failed stereotactic radiosurgery. Indian J Cancer 56: 151-156.

[16] Dincoglan F, Sager O, Demiral S, Uysal B, Gamsiz H, et al. (2017) Radio surgery for recurrent glioblastoma: A review article. Neurol Disord Therap 1: 1-5.

[17] Demiral S, Dincoglan F, Sager O, Gamsiz H, Uysal B, et al. (2016) Hypofractionated stereotactic radiotherapy (HFSRT) for who grade I anterior clinoid meningiomas (ACM). Jpn J Radiol 34: 730-737.

[18] Gamsiz H, Beyzadeoglu M, Sager O, Demiral S, Dincoglan F, et al. (2015) Evaluation of stereotactic body radiation therapy in the management of adrenal metastases from nonsmall celllungcancer. Tumori 101: 98-103.

[19] Sager O, Dincoglan F, Beyzadeoglu M (2015) Stereotactic radiosurgery of glomus jugularetumors: Current concepts, recent advances and future perspectives. CNS Oncol 4: $105-114$

[20] Dincoglan F, Beyzadeoglu M, Sager O, Demiral S, Gamsiz H, et al. (2015) Management of patients with recurrent glioblastoma using hypofractionated stereotactic radiotherapy.Tumori101:179-184.

[21] Demiral S, Beyzadeoglu M, Sager O, Dincoglan F, Gamsiz H, et al. (2014) Evaluation of Linear Accelerator (Linac)-Based Stereotactic Radiosurgery (Srs) for the Treatment of Craniopharyngiomas. UHODUluslararasi Hematoloji Onkoloji Dergisi 24(2): 123-129. 
[22] Gamsiz H, Beyzadeoglu M, Sager O, Dincoglan F, Demiral S, et al. (2014) Management of pulmonary oligometastases by stereotactic body radiotherapy. Tumori 100: 179-183.

[23] Demiral S, Beyzadeoglu M, Sager O, Dincoglan F, Gamsiz H, et al. (2014) Evaluation of linear accelerator (linac)-based stereotactic radio surgery (srs) for the treatment of craniopharyngiomas. UHOD -Uluslararasi Hematoloji-Onkoloji Dergisi 24: 123-129.

[24] Dincoglan F, Sager O, Gamsiz H, Uysal B, Demiral S, et al. (2014) Management of patients with $\geq 4$ brain metastases using stereotactic radiosurgery boost after whole brain irradiation. Tumori 100: 302-306.

[25] Sager O, Beyzadeoglu M, Dincoglan F, Gamsiz H, Demiral S, et al. (2014) Evaluation of linear accelerator-based stereotactic radiosurgery in the management of glomus jugularetumors. Tumori 100: 184-188.

[26] Sager O, Beyzadeoglu M, Dincoglan F, Uysal B, Gamsiz H, et al. (2014) Evaluation of linear accelerator (LINAC)-based stereotactic radiosurgery (SRS) for cerebral cavernous malformations: A 15-year single-center experience. Ann Saudi Med 34: 54-58.

[27] Sager O, Beyzadeoglu M, Dincoglan F, Demiral S, Uysal B, et al. (2013) Management of vestibular schwannomas with linear accelerator-based stereotactic radiosurgery: a single center experience. Tumori 99: 617-622.

[28] Dincoglan F, Beyzadeoglu M, Sager O, Uysal B, Demiral S, et al. (2013) Evaluation of linear accelerator-based stereotactic radio surgery in the management of meningiomas: A single center experience. J BUON 18: 717-722.

[29] Demiral S, Beyzadeoglu M, Uysal B, Oysul K, Kahya YE, et al. (2013) Evaluation of stereotactic body radiotherapy (SBRT) boost in the management of endometrial cancer. Neoplasma 60: 322-327.

[30] Dincoglan F, Sager O, Gamsiz H, Uysal B, Demiral S, et al. (2012) Stereotactic radiosurgery for intracranial tumors: A single center experience. Gulhane Med J 54: 190-198.

[31] Dincoglan F, Beyzadeoglu M, Sager O, Oysul K, Sirin S et al. (2012) Image-guided positioning in intracranialnon-in vasive stereotactic radiosurgery for the treatment of brain metastasis. Tumori 98: 630-635.

[32] Sirin S, Oysul K, Surenkok S, Sager O, Dincoglan F, et al. (2011) Linear acceleratorbased stereotactic radiosurgery in recurrent glioblastoma: A single center experience. Vojnosanit Pregl 68: 961-966.

[33] Stacchiotti S, Sommer J; Chordoma Global Consensus Group (2015) Building a global consensus approach to chordoma: a position paper from the medical and patient community. Lancet Oncol 16:e71-83.

[34] Sager O, Dincoglan F, Demiral S, Uysal B, Gamsiz H, et al. (2020) Adaptive radiation therapy of breast cancer by repeated imaging during irradiation. World J Radiol 12: 68-75.

[35] Sager O, Dincoglan F, Demiral S, Uysal B, Gamsiz H, et al. (2019) Utility of Molecular Imaging with 2-Deoxy-2-[Fluorine-18] FluoroDglucose Positron Emission Tomography (18FFDG PET) for Small Cell Lung Cancer (SCLC): A Radiation Oncology Perspective.Curr Radiopharm 12: 4-10.

[36] Sager O, Dincoglan F, Demiral S, Uysal B, Gamsiz H, et al. (2019) Breathing adapted radiation therapy for leukemia relapse in the breast: A case report. World J Clin Oncol 10: 369-374.

[37] Sager O, Dincoglan F, Uysal B, Demiral S, Gamsiz H, et al. (2018) Evaluation of adaptive radiotherapy (ART) by use of replanning the tumor bed boost with repeated computed tomography (CT) simulation after whole breast irradiation (WBI) for breast cancer patients having clinically evident seroma. Jpn J Radiol 36: 401-406.

[38] Sager O, Dincoglan F, Uysal B, Demiral S, Gamsiz H, et al. (2017) Splenic Irradiation: A Concise Review of the Literature. J App Hem BlTran 1: 101.

[39] Sager O, Beyzadeoglu M, Dincoglan F, Demiral S, Uysal B, et al. (2015) Adaptive splenic radiotherapy for symptomatic splenomegaly management in myelopro liferative disorders. Tumori 101: 84-90.

[40] Özsavaş EE, Telatar Z, Dirican B, Sağer Ö, Beyzadeoğlu M M (2014) Automatic segmentation of anatomical structures from CT scans of thorax for RTP. Comput Math Methods Med 2014: 472890.

[41] Dincoglan F, Beyzadeoglu M, Sager O, Oysul K, Kahya YE, et al. (2013) Dosimetricevaluation of criticalorgans at risk in mastectomized left-sided breast cancer radiotherapy using breath-hold technique. Tumori 99: 76-82.

[42] Sager O, Beyzadeoglu M, Dincoglan F, Oysul K, Kahya YE, et al. (2012) Evaluation of active breathing control-moderate deep inspiration breath-hold in definitive non-small cell lung cancer radiotherapy. Neoplasma 59: 333-340. 
[43] Sağer Ö, Dinçoğlan F, Gamsiz H, Demiral S, Uysal B, et al. (2012) Evaluation of theimpact of integrated [18f]-fluoro-2-deoxy-D-glucose positron emission tomography/computed tomography imaging on staging and radiotherapy treatment volume definition of nonsmall cell lung cancer. GulhaneMed $J$ 54: 220-227.

[44] Sager O, Beyzadeoglu M, Dincoglan F, Oysul K, Kahya YE, et al. (2012) The Role of Active Breathing Control-Moderate Deep Inspiration Breath-Hold (ABC-mDIBH) Usage in nonMastectomized Left-sided Breast Cancer Radiotherapy: A Dosimetric Evaluation UHOD - Uluslararasi Hematoloji-Onkoloji Dergisi 22: 147-155.

[45] Sager O, Dincoglan F, Demiral S, Beyzadeoglu M (2020) Evaluation of Target Volume Determination for Irradiation of Pilocytic Astrocytomas: An Original Article. ARC Journal of Cancer Science 6: 1-5.

[46] Demiral S, Beyzadeoglu M, Dincoglan F, Sager O (2020) Evaluation of Radiosurgery Target Volume Definition for Tectal Gliomas with Incorporation of Magnetic Resonance Imaging (MRI): An Original Article. Biomedical Journal of Scientific\& Technical Research (BJSTR) 27: 20543-20547.

[47] Beyzadeoglu M, Dincoglan F, Demiral S, Sager O (2020) Target Volume Determination for Precise Radiation Therapy (RT) of Central Neurocytoma: An Original Article. International Journal of Research Studies in Medicaland Health Sciences 5: 29-34.

[48] Sager O, Dincoglan F, Demiral S, Beyzadeoglu M (2020) Radiosurgery Treatment Volume Determination for Brain Lymphomas with and without Incorporation of Multimodality Imaging. Journal of Medical Pharmaceutical and Allied Sciences 9: 2398-2404.

[49] Demiral S, Beyzadeoglu M, Dincoglan F, Sager O (2020) Assessment of Target Volume Definition for Radio surgery of Atypical Meningiomas with Multimodality Imaging. Journal of Hematology and Oncology Research 3: 14-21.

[50] Beyzadeoglu M, Dincoglan F, Sager O, Demiral S (2020) Determination of Radio surgery Treatment Volume for Intracranial Germ Cell Tumors (GCTS). Asian Journal of Pharmacy, Nursing and Medical Sciences 8: 18-23.

[51] Sager O, Demiral S, Dincoglan F, Beyzadeoglu M (2020) Target Volume Definition for Stereotactic Radio surgery (SRS) Of Cerebral Cavernous Malformations (CCMs).Canc Therapy \& OncolInt J 15: 555917.
[52] Dincoglan F, Demiral S, Sager O, Beyzadeoglu M (2020) Utility of Multimodality Imaging Based Target Volume Definition for Radio surgery of Trigeminal Neuralgia: An Original Article. Biomed J Sci\&Tech Res 26: 1972819732.

[53] Dincoglan F, Beyzadeoglu M, Demiral S, Sager O (2020) Assessment of Treatment Volume Definition for Irradiation of Spinal Ependymomas: an Original Article. ARC Journal of Cancer Science 6: 1-6.

[54] Dincoglan F, Sager O, Demiral S, Beyzadeoglu M (2019) Incorporation of Multimodality Imaging in Radio surgery Planning for Craniopharyngiomas: An Original Article. SAJ Cancer Sci 6: 103.

[55] Sager O, Dincoglan F, Demiral S, Gamsiz H, Uysal B, et al. (2019) Utility of Magnetic Resonance Imaging (Imaging) in Target Volume Definition for Radiosurgery of Acoustic Neuromas. Int J CancerClin Res 6: 119.

[56] Sager O, Dincoglan F, Demiral S, Beyzadeoglu M (2019) Evaluation of Radiosurgery Target Volume Determination for Meningiomas Based on Computed Tomography (CT) And Magnetic Resonance Imaging (MRI). Cancer SciRes Open Access 5: 1-4.

[57] Dincoglan F, Sager O, Demiral S, Beyzadeoglu M (2019) Multimodality Imaging for Radio surgical Management of Arteriovenous Malformations. Asian Journal of Pharmacy, Nursing and Medical Sciences 7: 7-12.

[58] Beyzadeoglu M, Sager O, Dincoglan F, Demiral S (2019) Evaluation of Target Definition for Stereotactic Reirradiation of Recurrent Glioblastoma. Arch Can Res 7: 3.

[59] Sager O, Dincoglan F, Demiral S, Gamsiz H, Uysal B, et al. (2019) Evaluation of the Impact of Magnetic Resonance Imaging (MRI) on Gross Tumor Volume (GTV) Definition for Radiation Treatment Planning (RTP) of Inoperable High Grade Gliomas (HGGs). Concepts in Magnetic Resonance Part A 2019, Article ID 4282754.

[60] Demiral S, Sager O, Dincoglan F, Beyzadeoglu M (2019) Assessment of target definition based on Multimodality imaging for radiosurgical Management of glomus jugulare tumors (GJTs). Canc Therapy \& Oncol Int J 15: 555909 .

[61] Demiral S, Sager O, Dincoglan F, Beyzadeoglu M (2019) Assessment of Computed Tomography (CT) And Magnetic Resonance Imaging (MRI) Based Radiosurgery Treatment Planning for Pituitary Adenomas. CancTherapy \& Oncol Int J 13: 555857. 
Evaluation of Treatment Volume Determination for Irradiation of chordoma: an Original Article

[62] Demiral S, Sager O, Dincoglan F, Uysal B, Gamsiz H, et al. (2018) Evaluation of Target Volume Determination for Single Session Stereotactic Radio surgery (SRS) of Brain Metastases. Canc Therapy \& OncolInt J 12: 555848 .
[63] Demiral S, Dincoglan F, Sager O, Uysal B, Gamsiz H, et al. (2018) Contemporary Management of Meningiomas with Radio surgery. Int J Radiol Imaging Technol 80: 187190.

Citation: Omer Sager et al, "Evaluation of Treatment Volume Determination for Irradiation of chordoma: an Original Article”, International Journal of Research Studies in Medical and Health Sciences. 2020; 5(10): 3-8.

Copyright: (C) 2020 Omer Sager et al,, This is an open-access article distributed under the terms of the Creative Commons Attribution License, which permits unrestricted use, distribution, and reproduction in any medium, provided the original author and source are credited. 